\section{Disrupting the Ethical Imperatives of "Junior" Critical Qualitative Scholars in the Era of Conservative Modernization}

\author{
Penny A. Pasque', Rozana Carducci ${ }^{2}$, Ryan Evely Gildersleeve ${ }^{3}$, \\ and Aaron M. Kuntz ${ }^{4}$
}

\begin{abstract}
In this article, we wrestle with the core issue of how early career researchers translate central tenets and core concepts of critical theory and critical methodology into their research practice. By way of creative representation, we draw from bell hooks and Cornel West's (199I) written rendition of their verbal dialogue in Breaking Bread: Insurgent Black Intellectual Life. Their hope was to offer the book in a dialogic format in such a way that mirrored the synergy in their verbal discussions as friends and intellectual colleagues. In a similar vein, we hope to share with readers the synergy and depth of the narratives that have transpired during our ongoing discussions on the important topic of critical praxis as part of a collaborative research group called the Disruptive Dialogue Project (Gildersleeve, Kuntz, Pasque \& Carducci, 20I0; Kuntz, Pasque, Carducci, \& Gildersleeve, 2009).
\end{abstract}

\section{Keywords}

critical inquiry, dialogue, methodology

\section{Disruptive Dialogue}

Teleconference voice-over: Welcome. Please enter your conference access code followed by the pound key. [RC enters code and No.]. You entered [code]. If this is correct, press 1 . If not, please enter another access code. [RC presses 1]. There are three other people on this call. Please announce yourself *Ding*.

RC: Hello everyone!

PP: Hello Rozana.

RG: Hey.

AK: Hey Rozana. Penny just talked about collecting 12 eggs from her free-range chickens, Ryan described the details of his hot date last night, and I have to break from the call in a minute to get Oscar [2-year-old son] from the hot-tub. It's snowing in Vermont right now, so he can't stay in there long. How did things go with your committee?

RC: Great. Better than I could have hoped, actually. In fact, my experience was much better than Ryan's experience this week.

RG: O-M-G my on going drama with IRB continues. They're protecting themselves. I'm protecting the participants. No one's really protecting the process. It's a mess (Gildersleeve, 2010).

PP: That's terrible!
Qualitative Inquiry

7 (7) 571-588

sagepub.com/journalsPermissions.nav DOI: I0.1 | 77//10778004| | 409878

http://qix.sagepub.com

@SAGE
(C) The Author(s) 2011 
AK: What are you going to do about it?

RG: I have to-I get to meet with them in person again, next week. But you better believe I am keeping field notes on this whole event.

PP: Hang in there.

RC: Well, should we get to it? Where should we start?

AK: I'd like us to address the overall question we brought up last time of "how do critical scholars for social change engage in praxis in the contemporary era of conservative modernization" ala Michael Apple (2006). When I was reviewing the minutes from our last conversation, it seemed like a lot of us were relating to this issue and wanted to hear about the different practices that people utilize.

RG: I like it.

RC: I had a similar notion, because I haven't spent as much time reading about praxis as other folks have, but Aaron, I really appreciated the way that you broke down your understanding of praxis in our last round of memo's to each other. So for me the key piece is how folks take critical theory and the theoretical components of critical methodology and translate that into their research practice? I think of this specifically in light of the critique you and Penny did about empty theory (Pasque \& Kuntz, in press); how we do not always relate it to practice in every day conversations, and this lack of congruency was sort of taking the meaning away from critical work. A lot of people espouse critical work, but it gets lost in the translation to action.

AK: Right.

RG: Critical praxis operates on multiple levels, so it's not just that I have a critical research question ... .

RC: Right.

RG: . . but it's that my own research praxis in my daily practices as a researcher interacting with the folks that are involved in the project with me - such as community partners or graduate students - are congruent with my research. I see that as another level that has the potential to remove me away from critical work. There are multiple levels or spheres and it is important that I put theories and practice with communities together. I don't want to make a hierarchy of them, but I see practice not as something that is an outcome of a project, but it is a mode of the project.

PP: Exactly. It's not simply an outcome of critical inquiry, but actions during the entire congruent research process.

AK: To me, that is sort of what conservative modernization hinges upon; urging one and all to think in
$\mathrm{RC}$ : Some scholars argue that any rigorous research design that answers a critically informed question can be constituted as critical research. As Stage (2007) put it, "being a quantitative criticalist comes with the questions we ask, not the methods we use to answer them" (p. 5).

"The goal of this paper is to encourage language and daily practices that promote transformative research and teaching on social justice issues. Further, we seek to address institutionalized silence regarding teaching and learning pedagogies through exploring power relationships (Foucault, 1976) between rising scholars and current faculty via exploration of instructional vignettes. We argue that congruency between theoretical language and daily action may be fostered within the faculty / student relationship in order to encourage future scholars to actualize a connection between reflexivity, theory and practice. We explore the dissonance that exists between the current language with which we critically speak about our methodologies and potential transformative language among faculty and graduate students during a critical time of learning." (Pasque \& Kuntz, 2006, May)

AK: I'm struck by the many ways in which we are trained to reenact normative practices as students, as faculty, as well as the multiple ways our everyday activities are, themselves, a reproduction of norms. Yet such reproduction necessarily includes the promise of change - within the ongoing rounds of production there exists the possibility for productive deviance, whether conscious or not. Such deviances might occur on subtle, local, levels, within our practices of the everyday. Our work as critical inquirers, 
ways that are product oriented, not process oriented. Intentionally, a process orientation is deemed as too confusing, or it's too exhausting, or this, or that. Yet the energy that I have goes into looking at the process.

RG: And the process has no economic value in the conservatively modernized economy.

AK: Absolutely.

PP: And that "value" is the thing we need to shift.

RG: Right. Yeah.

AK: Yeah, I like that Ryan, and also what you were saying earlier Rozana, because I would think that a critical orientation, or a critical, methodological perspective requires an action component (Hytten, 2004). And, I would say we can't let each other off the hook by saying simply that the critical introspection or the critical analysis is itself an action. I think that it is, but I'm talking about actual material action, rather than only discursive action. Both are important. And so, I would tag onto what Ryan was just saying about multiple levels, and go with this notion of "critical inquiry" not being an end; it is a process of actions. This way, it can be both discursive and material, which means it can be the notion of action as it occurs in terms of doing what we do in our writing, and also the type of action that occurs when we engage in actual projects. And that's why I like the notion, actually, of the DDP-Disruptive Dialogue Project-as an ongoing process. You know? It can almost be the Disruptive Dialogue Process. You know? Because it's always already ongoing.

PP: I agree, and for me, it connects with some of the work in the field of communication, where scholars intentionally pull apart the "process" versus "content" (Pasque, 2010; Treholm \& Jensen, 1992). Process, in this case, could be discussions about the work, such as the Disruptive Dialogues or philosophical underpinnings of your research, as well as how you incorporate the process of critical research methodologies throughout your project. One example is working together with community members in order to draw out the research questions or the actual methods within the research process that would be relevant for all. Another example is when you consider what kind of process we go through in order to make sure the project is useful for the researchers and the community members - not simply to researchers. Consider the kind of critical methodological process as separate from or, to use Ryan's language, as on different levels than the content. We so often we get caught up in the content: What's the research finding? What is the most impactful literature to cite to get published? What then, might well be to create a space for such deviances, to manufacture room for alternative actions.

"The state of conservative modernization is marked by its desired and achieved outcomes, particularly the discourses it makes available for understanding education and its role in society. Conservative modernization shifts the social foundations of education to be primarily economic. Students serve as both consumer and product, albeit in different forms." (Gildersleeve et al., 2010, p. 89)

AK: Just quickly, I was at our faculty retreat and we were supposed to get together to talk about our research and teaching philosophy, where it came from, and this, and that. And of course, I'm ready to go. I'm like, "If we're going to do this, let's do this." So, I start talking about community engagement. I talk about micro/macro interaction. I'm talking about all of this stuff about the possibility for departmentwide projects that move beyond solitary, individual scholarship. I kept saying, "If we want to come together as a department, more than just administratively, then we need to have projects that we're working on. And, let me tell you Tuscaloosa needs more engagement from the University community, because right now the University is just using Tuscaloosa." And so I go on this spiel, and my senior faculty colleague looks at me and says, "Can you do all of that while you're on the tenure-track?" And I looked back at him and I said, "Well, how can I not?" He responded, "It sounds like something that only really you could do as a clinical professor because you don't have to worry about tenure." And I just felt like so pissed, you know. My hope is to be some degree of a social activist. But, on the tenure track, you sort of have to be both on all things, which is not an easy thing to do.

RG: I feel as though I'm now a development officer trying to secure funding, in addition to being all of these other things. And, when receiving messages like Aaron received about how you can't be an activist or engaged in the community, part of me keeps returning to this question of, "Why don't I just start my own non-profit that does community-based research." If the academy is going to force me to play all these games by their rules and processes, why don't I play similar games, but by my own rules, in a way that is more congruent to what critical inquiry values, and the principles of critical inquiry? Where I can establish these principles as the guiding principles of the organization. 
are your research findings? However, that ignores the whole research process, itself. It makes an assumption that if you have a critical question, you'll be doing critical research. It's not so. I like taking the content and process of critical research apart, then putting them back together, as opposed to ignoring one or the other.

$\mathrm{RC}$ : I mean those questions are necessary, but not sufficient from a critical methodological perspective. Is that what you're saying?

RG: Sorry, can you repeat that question.

RC: Hello?

AK: I think you have to repeat it.

RC: Oh, I'm sorry. I think it's Ryan. Somebody's got a lot of static on their phone. Um.

PP: I'm hearing a lot of clicking.

RC: Yeah, it's static.

AK: I'm hearing a lot of static too.

$\mathrm{RC}$ : So, Ryan, were you saying that reflection is necessary, but not sufficient, for sort of a critical methodological praxis?

RG: I was saying that reflection does not equal critical praxis. Reflection is required but it is not the end game. Just because you're reflective, doesn't mean you're necessarily engaged in critical praxis. That reflection has to be connected to action in each moment within a research study.

RC: I want to go back to action then, because I think that's the piece I really struggle with. What does that - not have to look like, you know you never want to set definitive boundaries - but what is that? What do we expect? For example, in terms of community engagement that Ryan brought up earlier; What does that look like? Engagement with the population? The students that you work with? Right?

RG: Right.

RC: So, again, I think back to the American Educational Research Association (AERA) symposium (Kuntz, et al., 2008) when Gretchen Rossman and Sharon Rallis questioned that I was becoming more ideologically committed to the need for participatory action research when I think about my own critical methodological framework. I really do believe there's an engagement piece. That action piece, for $\mathrm{me}$, is about becoming more and more linked to the folks that I'm attempting to understand and study, and foster social change in that community. And so, what do we think is action? If a researcher does a study on campus racial climates, presents those findings at a national conference and writes up a policy paper to publish in Change magazine, is that action? Is that a critical methodological approach, because the researcher is not publishing it in a peer reviewed
AK response to $\mathrm{RC}$, International Congress of Qualitative Inquiry (ICQI) 2008: Certainly, there exists academic practices that remain on the margins, sometimes going unrecognized by the lens of the academy, though remaining no less important, no less powerful. Rozana locates several of these- - letters to the editor, community networking, to name but a few — and asks us to consider how such practices might disrupt traditional educational training.

And so I return to my own practices as a junior faculty member teaching an introductory qualitative research course to graduate students. When I scan my syllabi, I rarely see any incorporation of these marginalized practices in my assignments. Though my syllabi certainly incorporate readings that are overtly political and seek to provoke progressive political change, I do not ask the students in my classes to practice similar types of writing or take their academic work for my class out into the political realm. Writing letters to the editor or engaging in community organizing are not articulated objectives for my courses. In a very real sense, then, I perhaps encourage my students to read critically, and perhaps even to write critically, but not always to engage in political practices that go beyond such classroom-based performances.

A large part of this no doubt extends from my own probationary status along the tenure-track as I strive to create courses that are seen as a resource to my larger college and not alienate me or my students in the eyes of the more senior faculty. 
journal, but publishing it in something that's more accessible to administrators? You know what I mean? Like, does that question make sense?

RG: What was that again? Sorry, I was distracted by a "who wore it better" picture of Britany Spears and Fergie on my screen.

RC: Does research that asks critical questions and is shared in a venue for practitioners, but that does not incorporate critical research within the entire research process count as truly critical research?

RG: I still don't think so because, again, it gets to the multiple levels issue. For example, if the research is not doing anything with the administrators other than publishing, that - for me-is not critical engagement. It is being a good citizen, you know? It's not critical engagement or critical research.

PP: To me, this connects with, and I know we talked about this before, Patti Lather's $(1986,1993)$ concept of catalytic validity. She talks about it as the degree to which the research process reorients, refocuses and energizes the participants in knowing their own reality in order to better inform it. In this sense, community members participating in research also learn from the research process and this informs community action and social change. Otherwise, there can be this strong power dynamic that is infused with objectification; I'll research "you" and tell the academic community what "you" think.

AK: Right, and I think there needs to be an element of change on both sides. If the researcher comes in and works to change communities, but is not fully engaged with the communities, the researcher remains unchanged. Essentially, there needs to be a reciprocal dynamic process between the researcher and the community. Far too often I think the way in which we engage in the research process is sort of unidirectional and the researcher does not reflect upon or learn from the study. When I think about doing program evaluations for example, I teach in my classes that a basic tenet of good program evaluations is that when and if you're no longer involved in the evaluation you leave some evaluative component there, so the evaluation continues after you leave. That element is in place for there to be actual change in the communities. The hope would be that you'd still remain there, but for me I like the notion of process of change in which the researcher and the community in which the researcher works both evolve.

RC: It's the publication piece, for me. No matter where you publish it, if it's About Campus or Change or the Review of Higher Education, if your goal from
Change is a magazine dealing with contemporary issues in higher learning. It is intended to stimulate and inform reflective practitioners in colleges, universities, corporations, government, and elsewhere. Using a magazine format rather than that of an academic journal, Change spotlights trends, provides new insights and ideas, and analyzes the implications of educational programs, policies, and practices. Retrieved from http://www.changemag.org/About\%20Us/index.html

AK: I'm thinking more of France, you know? In the 1960 's, faculty and students were doing some pretty radical stuff, and they managed their position within the academy as a way to sort of serve those ends. I just think if there's been even a smidgen of hope that it's happened in the past, I want to use that as fuel to move forward, although I have to say I don't quite know, I'm at a loss in terms of how to make that happen.

PP: Well, and for me, it can happen in the classroom, in the conversations about higher education administration, student affairs, and through teaching diversity in higher education. For example, in the "Diversity in Higher Education" class I teach, we're having this engaged dialogue about the complexities of race, gender, class, sexual orientation, religion, etc., then graduate students are going out into their work environments, and then coming back and sharing their own stories of social change. They share that "this is the impact that I made" or "my supervisor said, "wow you've really grown in this last year around issues of diversity in this engineering 
a critical methodological perspective is fostering social change and empowerment then publishing as your primary method of action doesn't cut it, because how is that empowering? I mean I guess it could be empowering, if another academic reads it and thinks, "Aha, this is a piece of knowledge I can apply in my own community!" But I just think it's too passive in terms of fostering the kind of change that I'm interested in. You know? I recall reading a great chapter by Fine, Weiss, Weseen and Wong (2000) in the second edition of the Handbook of Qualitative Research that calls upon scholars to reconceptualize the process and products of socially responsible research. The authors challenge doctoral programs to cultivate the methodological skills, knowledge, and commitments essential for engagement in the multiple sites of social change. These sites include scholarly journals and conferences as well as courtrooms, popular media, church and civic groups, and legislative bodies. What I appreciated about this chapter is that it did not set up a false dichotomy: either you are a passionate change agent who seeks to empower others through grassroots activism or you are a serious critical scholar who conducts rigorous research and disseminates your knowledge in journals with high impact factors. This is not a choice that needs to be made or should be made. I agree with Fine et al.'s call for the cultivation of qualitative scholars capable and comfortable engaging in the multiple facets of social change. That is the kind of scholar I am aspiring to become.

AK: Right. I have been moved by our discussion about how to work within the context of us all being emerging scholars - or emerging - whatever. I guess just generally emerging. Rozana, you are really hitting on a sensitive topic for me. My whole job orientation has been couched in my relation in my ability to produce within the publishing world. Right? So engaging with that as a critical scholar, my only way to really do it is - like I said at ICQI (Pasque, Carducci, Gildersleeve, \& Kuntz, 2008)is to set up a means for me to engage in the community that uses similar, if not the same types of skills and abilities, but in which I refuse to do anything in terms of publishing with it. This may be a really strange reaction, but it's the only way that I can figure it out enough to feel like I can honestly engage with the community, and not feel like I'm potentially exploiting them to some degree. And yeah, there's probably a ...

RG: You ...

AK: Oh, go ahead.

RG: Um, you finish your thought. I apologize. office." Those are the comments that I hear that make such a difference to me. It's not about me, I'm not doing it, but I'm fostering a space for people to think through the complexities of the situation, then do it together; the process and action pieces that we discussed already.
AK: And, this also goes with this dossier junk I've been having to put together. You have to establish yourself as a scholar on "your own terms." Like, you have to put that sort of in quotes, as solitary, and as isolated. Right? Because you can't say that you're qualified based on your connections to communities or your connections to other people. You have to say that you're qualified because "On my own, in isolation, I created these works that were published in these areas." In this way, the whole structure is based toward solitary occupations. And what that encourages is a degree of ownership and territoriality. You have to show the territory of the landscape that you own (Kuntz, 2007, 2009).

PP: And it sets up this pattern, or the academy is already set up with a pattern that perpetuates this dominant paradigm of people working in isolation in order to keep people with alternative agendas marginalized, and not to provide a place where we really could develop critical colleagueship, as Aaron was talking about. 
AK: No, it's okay. I was just gonna say it's probably like a steam valve release for me, but it's a very necessary one.

RG: So, Aaron, I missed the beginning. Did you say that you choose not publish anything from work with that community, or only to publish ...

AK: I choose not to publish.

RG: Okay.

AK: Yeah, so I really make it known, because I don't know about how you all-I think it's my own sort of warped perception - but often you can get into these communities and feel like, "Oh, how would I frame that, and what journal might be interested in this type of experience?" You know? And I think it's kind of gross.

RG: And, I feel gross when I think about it. I have moments where, usually after I've met with my department chair, where I think about a neat idea for a project or an article, with a particular outlet, and then I think, "How can I manipulate what I have going on with different people in order to achieve that?" And then when I catch myself in that moment; I'm like, "How messed up is that?"

AK: Totally. Like when my assigned mentor who I went to lunch with every month said to me, "You know, there's an economy at work here, and that economy is publication, and we expect that you are going to take part in that economy." I'm thinking, "Woah, hold on a minute. I don't even ... I want to sort of critique that economy from the beginning, first of all. And second of all, if my subsistence or my ability to continue within this community is dependent upon my production of academic scholarship, then that becomes problematic to me as a critical scholar.

PP: And, we've talked about how it's really a piece of cyclical oppression when you look at it in terms of tenure and promotion for junior and emerging faculty members. If you don't do it in a certain postpositivist manner, then you don't necessarily get published in top-tier journals, and if you don't get published in top-tier journals, then you don't get tenure.

AK: I have to get off for a minute to go get Oscar. I'll be back.

PP: From here, you don't have incentive for people who are doing critical thoughtful work with the community for change if they're also trying to get tenure. Then, if you wait until after tenure, there are other pressures and you haven't necessarily established a strong relationship with a community. Tenure was established in order for people to have freedom in terms of their research, speech and
RG: I think what we're really talking about here is the truncation of knowledge: point blank!

RG: I got an email from a colleague in my department here, and she's working on a book chapter about how to make the academy a more welcoming place, or a place where - she calls it "folks like us" - can belong. What she means by "folks like us" is scholars of color, or scholars who participate in marginalized scholarship. Be that critical scholarship, or scholarship about and with marginalized communities, that type of thing. But her follow-up question was less about what's constraining, and more about what would you like to see changed in the academy that would make it more welcoming? That would make it a better place? And I've not been able to answer that question, because I think it takes a fundamental restructuring of how academic life is organized. And so I like, along with Aaron's attitude, I really like his idea of infrastructure. And then, recognizing that it's really difficult to build local networks or local support, because the structure of the academy today separates us.

RG: And even downstairs in another department, one colleague, Katie, whom I have collaborated with (we do it almost at arm's length for political reasons) we both want to build a coalition together, but we also need to look very, well, we have to look as we're independent autonomous scholars, where it's not just "Katie and Ryan's show." Honestly, part of 
teaching; exactly the reason we're talking about this as critical qualitative methodologists. This cyclical process only allows certain types of scholars in the door.

AK: I'm back.

PP: And so what you're talking about, Aaron, is a critique of the system, and how do we find alternative paths within the academy? This way, you can work toward tenure, if that's the goal, so you really have an opportunity to do critical work. Some of the advice from my colleagues has been, "Oh, well you don't do that until after you get tenure." But what is that?

AK: One of the things the faculty activists that I've studied all said is that they didn't really wait until they got tenured, however once they got tenure their administrative requirements jumped (Kuntz, 2007). This meant they had less time to do other things. So I just bring that up to say, even getting tenure doesn't do anything, it doesn't cut it, because it's five or six years down the road. So, I'm going a little nuts with that quandary. I'm not at a point where I'm ready to leave the academy. And, how can I stay and still work within? Maybe just give me a little bit of time to get cynical and then I'll be ready to leave, but I'm not quite there yet.

PP: For me it's not necessarily about living in two worlds-although there might be two separate worlds at the moment - but where are the crossovers? I don't want my career to be that dualistic. I want the corners of my life to blend. I want to have a system where the energy and time and effort people are spending doing emancipatory research is given credit within the academy. For me, some of that happens from within the system. For example, when we are the journal reviewers, or craft a qualitative research syllabus, or serve on tenure committees, we need to be the people who make the change from within. Or, at the very least, raise questions about the status quo.

RG: Along with you, I still hold out hope and a belief that the academy can be, and has the potential to be a transformative space. I have yet to resign myself to the idea that conservative modernization has become ubiquitous, that it has taken over completely. But it is definitely the dominant mode, and the mode that exercises the strongest power right now. So, how do we live in these two worlds? I'm with Penny in that I'm trying to craft a new resistant corner of the world in the academy. Not necessarily new, but conjoined with other transformative spaces in the academy. what's hampering our collaboration at this point is that once I joined her, the work started garnering attention. She'd been working in the community for four years already and no one ever paid attention to her work. It's like suddenly this White man comes in and we got tons of invitations to different meetings last year, all as addressed to Katie and Ryan, or to Ryan and Katie, "based on your work in Marshalltown." It's like Katie has been in Marshalltown for four years. I've visited there about four times. You know? And she used to go every week to Marshalltown for her first two years here. And so that's really messed up, and that made us each recognize that we can work together but we also have to sustain our separate identities and allow ownership of our work. Which, it's strange for me to think about "ownership" in research.

PP: Here are these pervasive issues of power again. And so, if you have somebody who, like Ryan, can acknowledge the power and work it through with her, that's great. Yet, it's still within the system that perpetuates this oppression, of women, of people of color, of marginalized research, and more. Sometimes you need that ally to say, "Wait a minute, this is not okay. You need to pay attention to the work that's been going on for four years. And my role is only one part of this ongoing project." But not everybody is willing or able to do that, especially when they get recognition for their work. Then, where do we take it in terms of the people who can recognize and own, "okay here's where I have power? How do I use it as an ally in this critical colleague relationship? How do I use it for good in a sense, or to make change, and work on it with her?" From here, how do we take it to the next step of changing the overall culture and seriously really providing support for people to have voice and try to make that change in the academy, particularly since the white guy will often get support for taking credit for the community research. 
RC: So Ryan, what does it look like to craft that corner?

RG: Well, I think I need to let go of a vision of it being wonderful where I wake up completely refreshed every morning and excited and fully supported. I think that's what I was hoping for with colleagues and students and staff and research participants, or whatever. I think I need to let go of that, and start to recognize that there's going to be struggle in that all along the way. But in the micro-practices, it comes down to figuring out, "Where is funding that my project and I can work with, and can go to bed with, and not feel like whores?" And publication is less a struggle for me-I mean, I struggle to publish, don't get me wrong — but it's less an ethical struggle for me, in the sense that part of our project (part of most of my projects, I would argue), is trying to disrupt that master narrative that gets fed by the dominant representations and publications. But, the micropractices involve a lot of fighting; that is something that I don't know I was necessarily prepared for when I graduated from UCLA [University of California, Los Angeles].

RC: I like the way you framed that the publication piece is disrupting the master narrative. I mean, I really appreciate that, because it sort of reframes the "publish or perish" dynamic.

RG: Right. I have to go there, because honestly I do publish because it's my job.

RC: Right! And you can't ignore that! I mean I think that's the piece- - you can't resist that and still stay in the academy because you're not going to pass the test, you know? So I think that's a great way to frame it, but at the same time, you do have community engagement. You have to get involved with communities, at least, that's an imperative from my framework. You know? For example, it was so disheartening because I was involved with a project where the attitude was, "Let's go in and interview these people, gather their secrets, and publish it." And while the publishing may serve to disrupt master narratives of leadership, in no way were we ...

RG: But those practices you found really dehumanizing to those people.

RC: Yeah, we weren't in any way engaged with a community that thought about what their needs were; what would be helpful for them. I mean, there was just no engagement piece. For me, there is an engagement piece that you can't ignore. I constantly find myself turning back to Brown and Strega's (2005) Research as Resistance. For me, this book captures the essence of civically responsible educational scholarship-research driven by the
RG: I've decided to sort of pull out of Marshalltown with Katie. And this feels strange for me, but it's a very territorial thing. I want-politically, I don't think it's appropriate for me to march into Marshalltown. And, it's strange to put it in those terms, and use that metaphor, but that's how it feels to me based on the institution's response to my involvement and participation.

AK response to RC, ICQI 2008: One way that I negotiate all of this is to create spots of opportunity or potential within the classes I teach. I never feign a politically neutral stance in my classes, but instead strive to show myself as politically - and passionately-invested in both the concepts we discuss and my own work as a critical qualitative researcher. I model political positioning within the classroom in the hopes that students will feel comfortable enough to position themselves politically, to see themselves as engaged in political research no matter what their future dissertation topic. Perhaps more importantly, I strive to create space for my students to feel politically connected to the world outside of the classroom, to resist the isolation that is all too common among graduate work and academic work in general.

RC: I find this particular passage from Research and Resistance particularly compelling and relevant to our discussion of critical praxis: "By centering questions of whose interests are served not only by research products but also in research processes, [critical and indigenous approaches to research challenge] existing relations of dominance and subordination and offer a basis for political action" (Brown \& Strega, 2005, p. 10). 
understanding that the research process itself, not just the research product or outcome, is a vehicle for advancing social justice and enacting democracy (Potts \& Brown, 2005). It is a process of inquiry that intentionally disrupts relations of dominance and structures of subordination via collaborative inquiry practices and political action. I see this notion of civically responsible research exemplified in the critical methodological frameworks of feminist inquiry, critical race theory, participatory action research, critical ethnography, indigenous research, and photovoice methodology among others-all methodological frameworks which reject the assertions of a master narrative (Stanley, 2007) that continues to define rigorous and therefore legitimate educational scholarship as objective, context-free, color-blind, and politically neutral. Civically responsible educational scholars enact a counter narrative, conducting research that is context-bound, explicitly political and personal, and democratic in both aim and practice. For example, action researchers seek to co-generate knowledge of use in resolving real-life problems via collaborative inquiry processes that engage local stakeholders in the design and management of the research initiative as well as the implementation and evaluation of research findings (Greenwood \& Levin, 2000).

PP: Definitely. We've also talked about working with communities as opposed to working for communities. Someone said earlier, "I don't want to come in and exploit communities." Yet, the tenure process seems counterintuitive for critical scholars. There's this paradigm in the academy that reads, "I have to find a research project so let me work with this community in order for me to have a new agenda," as opposed to really engaging together with the community that you are a part of in a long-standing relationship. In this way, critical scholars resist the ever-present tendency to go in, do an interview, come back out, get what you need-which again feels very exploitive, as we talked about before. The alternative is to engage in a long-standing positive relationship, where you're drafting a research agenda together, and where the research is molded and changes and moves together based on community and researchers needs, just as Ryan brought up earlier.

AK: Yeah, I totally agree with you Penny. The difficulty that I run up against is that I've always said that I wanted to be able to work in local communities and the question is, as much as I like my job, am I always going to be at this university? So the ethical question becomes, "How am I going to sustain a
All: An anonymous reviewer of this manuscript observed that we seem to be separating our scholar and activist identities in our efforts to simultaneously fulfill tenure expectations and engage in transformative research. The reviewer commented, "For some of us, the division between scholar-activist is at least blurred; it does not make sense anymore." Indeed a number of scholar-activists have written about their efforts to disrupt traditional notions of researcher objectivity, stable and discrete subject/ observer identities, and politically neutral scholarship via the adoption of critical qualitative methodological frameworks that support the enactment and representation of fluid, overlapping scholar-activist identities (e.g., Brown \& Strega, 2005; Denzin, 2003, 2005; Diversi \& Moreira 2009; Fine, Weis, Weseen, \& Wong, 2000; Hale, 2008; Jones, 1997). For these scholars, research can and should be conceptualized as a form of activism and their activism serves as a powerful source of knowledge. While we agree completely with the reviewer that critical qualitative methodological frameworks call upon researchers to blur, if not all together erase, the distinction between scholar and activist, we feel that our dialogue on this subject captures the tension we have faced as early career faculty socialized and located in institutions of higher education framed and constrained by the tenets of conservative modernization (Apple, 2006) and methodological conservatism (Lincoln \& Canella, 2004a). The dialogue represents our ongoing efforts to individually and collaboratively "work the hyphen" (Fine, 1994), drawing upon the insights of those scholar-activists who have come before, yet recognizing that we must cultivate our own unique scholar-activist identities and practices. As evidenced in this manuscript, this process of identity development is very much a work in progress.

RG: At the same time it comes back to what I think is the emerging of the critical question: How do you do all that and build and sustain an infrastructure so that other people can participate? You know?

PP: That is not rewarded.

RG: That's right, so um, that's not rewarded and is part of an overarching theme that we seem to be talking about; how you put your energies into unrewarded behavior and still sustain on the tenure track, you know, sustain your existence?

AK: As Apple (2006) puts it, "Who we are and how we think about our institutions are closely connected to who has the power to produce and circulate new ways of understanding our identities" (p. 8). 
long-standing relationship with a community when I might not be there for longer than two or three years?" You know?

$\mathrm{RC}$ : That is a real palpable challenge.

AK : Yeah, and I — as an aside - I just would say that a lot of what we're talking about seems to me to be really symptomatic of what we've started to learn about in terms of conservative modernization and neoliberal thought, right? I just see it as symptomatic of this process. This is an ongoing process, so we begin to get into all these sort of ethical dilemmas that we want to address and at the same time we feel very stuck. And that, I think, is symptomatic in terms of what we've talked about in terms of the era of conservative modernization. Then, Rozana, I think it was you that had this lovely turn on it where you talked about conservative methodologicalization or something, or conservative methodological practices that extend from that perspective. At this point, you start to alter your actual research practices to meet the needs of this era that we're in. RC: Yes, at our ICQI 2009 symposium (Kuntz et al., 2009) I discussed the methodological conservatism that has resulted from the Right's escalating influence in the academic arena, advancing educational research and policy guidelines such as the No Child Left Behind Act (2002) and the Education Sciences Reform Act (2002) that narrowly define notions of quality research and legitimate inquiry (Bloch, 2004; Lincoln \& Cannella, 2004a; National Research Council, 2001; Schwandt, 2006; St. Pierre, 2004). Seeking to protect their political, economic, and cultural powers, the Right has aggressively pursued the adoption of science- and evidence-based research frameworks which seek to undermine, if not outright reject, participatory and empowering research methodologies of critical inquiry. Critical scholars such as Denzin and Giardina (2006) and Lincoln and Cannella (2004) cite the imposition of this neopositivist educational inquiry framework as an example of the methodological conservatism, which frames and constrains university research in this era of conservative modernization.

PP: And, researchers are experiencing a push-back throughout the country. For example, researchers in the Detroit area are saying, "Okay, let's work with the Detroit, and help the educational environment in this urban area, blah, blah, blah." Right? Some researchers are going in with a paternalistic attitude and thinking they're going to make it better. There are people in the Detroit community right now who are saying, "No way. We've had researchers come in here for years. What have we gotten
RG: So, I've started to develop relationships with this other town called Perry (Gildersleeve \& Ranero, 2008,2010 ), which is also a demographically transitioning environment, and I've been working with the middle school there, and they are eager to work and collaborate. They say, "Show us what you can do with us. We'll share what we can with you." An administration at the middle school level, at least, that's eager to address the issues that they recognize they are facing, and are ill-equipped to handle on their own. But, also not looking to me to solve anything, and not looking at me as the expert coming in, but as someone who's willing to struggle with them.

AK: Yes.

RG: And that feels really awesome. I want to invest more time and energy in Perry as a community via the middle school right now. I do think it takes at least two years of investment of individual time and stuff before anything could truly become sustainable. You know what I mean? 
out of it? You're actually helping to perpetuate the situation that has been going on here in terms of the deteriorating educational, economic, business, housing, and other systems. We don't want it. We don't want you to come in, do your research, then leave." Further, when you talk about this type of sustained research, it really is time consuming; on community members end, on researchers end, in terms of the relationships, in terms of doing it well. And so here, again, is the struggle that you're talking about Aaron, in terms of "Hey, I might not be here for very long, so do I really want to commit to that kind of relationship, because I know all that a reciprocal relationship really entails? I know what the community of Detroit really deserves." Yet, to do nothing helps to continue to perpetuate this era of conservative modernization and the status quo.

RG: And that, to me, brings up two points. One, the work that critical scholars do is dangerous in the sense that it's dangerous that it so easily leads to really messing up communities, or messing communities up, or messing with communities. And, at the same time, I think that the conservative modernized academy pushes us to that dangerous spot in the sense that, in order for any of us to meet our promotion and tenure expectations it would be easiest to do so if we didn't care about the communities in which we are engaged; if we pimped them out, basically. But because to sustain - and that's the critical praxis comes in for me-in order to sustain and walk that fine line, I have to be consistently and constantly engaging with the community in a reflective manner to make sure that isn't happening. But furthermore, I think the struggle is to find ways to engage critically in research with communities so that if I were to leave, then my absence doesn't necessarily mean that the project fails. Like the new artifact that I now live in Iowa instead of California hasn't stopped Los Estudiantes Migrantes y Educación (LEME) from continuing. Quite the contrary, actually. Since I left California, the student participants have taken on more leadership within the project - partly out of necessity and largely out of their own developing critical praxis. You know what I mean? And that to me is the trick. One of the tricks. One of the trickiest things to figure out is that the community should be able to continue the work, whether or not I'm there.

AK: That's such a good point. Yeah.

PP: For me that resonates with how I worked to develop programs as an administrator. For example, in the Michigan Community Scholars Program (Galura,
RG: Scholars have written about dangerous research, but generally it falls into two categories: (a) how sites can be dangerous to researchers (Sampson \& Thomas, 2003; Nilan, 2002) or (b) the dangers (and politics) of representation (Arruda, 2003). What I'm working toward here is more along the lines of how we as criticalists are dangerous to the communities with which we engage in our projects (Smith, 1999).

PP: As I revise this article, I am working on a computer in the University of Michigan main library. Two men just walked by and one said to the other, "and, that will help us to bring in those big, high-rolling donors." Honestly! The pressures of academic capitalism (Slaughter \& Rhoades, 2004) and intellectual sustainability are pervasive throughout the academy as education, politics, prisons, environment, and other industries compete for dollars. We feel it in our annual review processes, job searches, and daily conversations while walking through the library. In what ways do we have to reduce the integrity of the research project, forfeit an equal community partnership, translate a critical inquiry project into palatable language, "sell our souls," or settle for a balance between critical inquiry and academic capitalism to survive in the academy?

Los Estudiantes migrantes y educacion is a grassroots collaborative critical ethnographic project between 12 Mexican migrant students and one university researcher. The goal is to revolutionize educational opportunity for migrant families through critical consciousness and material change of the sociocultural mediators that preclude migrant social opportunity (Gildersleeve, in press; Gildersleeve \& LEME, 2009).

AK: And I want to be ethical, and I want to be- to a degree - consistent. I want to be engaged in practical ways. So I'm hesitant to say, "Okay, in two years I might be gone." So, then I produce this hesitancy to get involved in the very communities that I could be involved in, whereas, some might say that my involvement in the community might produce small 
Pasque, Schoem, \& Howard, 2004), there were faculty, students, staff and community partners; all these people connected to build the program but we set it up in such a way where oral tradition was used. Oral tradition is often used with undergraduates to learn about the culture and climate of an institution and life in college, but is not often intentionally discussed when the new leaders come into a program and the older leaders move on (Pasque, Franklin \& Luke, 2004). I worked to set up mechanisms to yoke the strength of that process and for the older student leaders to select, hire, and train the new leaders. In this way, you create a shell, but yet when the director steps out of it, the program continues on as students lead. So what I'm hearing from you, Ryan, is, "how do I take what I know how to do as an administrator and apply it to the research in such a way where that same sustainable elements continue to happen?" And, I don't necessarily think we have many good models for that in academia. I think yours is a great model, and there are a few others. This leads me to Rozana's initial question about how; "how do I do that?"

RC: For me that exchange was about that it's not just about the research and the knowledge production, but it's also about helping to facilitate infrastructure. Right? I mean the reason that Ryan's project has been able to continue is because he was committed and invested and thoughtful about the project infrastructure that allows it to continue despite the fact that he doesn't live in California (Gildersleeve, Gomez, \& Rodriguez, 2009). Right? So, I think Penny you make an excellent point that as critical methodologists, it can't just be about the research, but it's got to be about the organizational dynamics that we aren't trained to really think about as scholars.

AK: Yeah, I think that's a great point. And actually, I'm sitting here thinking that we're starting to get toward one answer of how do critical scholar engage in praxis in the contemporary era of conservative modernization. One is that we're maybe working to build infrastructure. Right? Or that we acknowledge the infrastructure that's always there and create an alternative paradigm. But the other is, now that I'm teaching introduction to qualitative research, for example, instead of just saying, "How did you analyze the data?" I might ask them, "In what ways have you established some sort of infrastructure for this research project?" is jumping out at me but I would want to have a better term. "How are you engaging with the community so once you're gone, openings or interstices for everyone to get involved. You know what I mean? And again this is just coming to me now, but I wonder how much I'm sort of parroting that linear institutional perspective of progression.

RG: Wow, that's deep.

PP: Mmm-hmm.

AK: I don't know if it's true yet, but it is something I want to be suspicious of.

AK on reflection of this dialogic article: In the interest of keeping that self-reflective eye on ourselves, I'm wondering how much we are beginning to buy into that world of linear mobility, where you are always moving in unidirectional ways.

PP: If all research is political, then how would we define critical action research? Further, how would we develop this infrastructure, or facilitate an infrastructure to support our definition of critical action research in education?

AK: Well, it is a really difficult thing to envision. Because I think that it ... Well, let me backtrack a little bit, it has to happen through a degree of authentic connection, which is why I love the DDP so much. Right? So you begin to build a supportive environment that, in turn, is self-reflective enough to critique our processes. Like Ryan, you did that nicely in our phone call to your class [earlier, we were guest speakers via teleconference]. You said we have to be aware of what we represent-of whose voices might be silent, where our blind spots are. I'm starting to do this - and I hope this is on topic - but I'm doing this research on critical colleagueship, which is this idea that if you really want to create strong, critical scholars, you have to have a support structure for critical colleagueship. Unfortunately the makeup of the higher educational system doesn't support it, because you have to find critical colleagueship most often outside your department for political reasons, and most often off-campus. That means that it's difficult to create local activism. It needs to be discipline-wide or beyond the scope of your local area. And that, to me, is really troubling. And so when I start to think of critical engagement through research, I start to 
parts of it continue?" Or, "What is continuing now that you're gone?"

RC: Right.

AK: Maybe that's a better way to ask.

RG: I like that. I like that a lot. What is continuing now that you're gone?

AK: Yeah, and I think that's the question that I know I was never asked in my doctoral research. You know? Or in my research methods classes. And so I'm glad we're having this conversation, because now I'm thinking that could be a whole section of a course. It would be interesting if there were readings that address that issue. Consider questions such as, "what is continuing? And the sub question or the hidden question behind that is potentially, "what are you perpetuating?"

RC: Right. And you've got to start thinking about that at the beginning of the project. "How am I designing this? Or, "how am I collaborating on this so that it's something?" "What does continue?" You've got to start planning for that and working toward that at the very beginning. You know?

PP: And it connects to ...

RG: For me it comes back to how am I disrupting the normative social expectations. How am I disrupting the normative social dehumanizing practices of today?

PP: And - this connects to the work that we were talking about from Milner (2007) when he talks about how researchers are not mindful of the enormous responsibility of their own and others' radicalized positional, and cultural ways of knowing. The results can be dangerous to communities and to individuals, so awareness around power and sustainability is crucial. And so, we're talking about "do no harm." Well, yeah, do no harm has been taken one way by IRB and researchers in terms of how we're taught, but yet we're asking people to make it deeper in terms of the ways in which we are working with our communities, helping to support our communities, resisting dominant paradigms, and actually making social change that's so desperately needed.

AK: Yeah, absolutely.

RG: Yeah.

RC: Yeah.

RC: What are the steps we should take from here?

PP: I'll send the minutes out after this call.

AK: I'll work on drafting a related proposal to the International Congress of Qualitative Inquiry for May.

RG: I'll finish up the re-writes on our "revise and resubmit" article and send it to everyone to review by think, "How can we bring it down to the local level?" because that's where I live, it's where I operate, and it's troubling to me that I obviously haven't been able to do that, I guess.

"Anti-oppressive research involves making explicit the political practices of creating knowledge. It means making a commitment to the people you are working with personally and professionally in order to mutually foster conditions for social justice and research. It is about paying attention to, and shifting, how power relations work in and through the processes of doing research." (Potts \& Brown, 2005, p. 255)

RG: Transformation is change in participation over time (Rogoff, 2003). The change of a system of activity over time (Engestrom, 1999).

AK: I would go back to what we were talking about earlier where, instead of considering these things as products, how do they work in terms of their process orientation. I would say, "well, what's the affect of the process of them engaging in the research." This is where I come at it in terms of the critical methodology and methodologists.

RC: Absolutely and I think that's the piece for me that, and Aaron you came back to it, is that process. Right? I mean there is that "how?" This is reflected in that Kinchloe and McLaren (2000) quote we write about, that traditional research practices (traditional quantitative and traditionally qualitative) replicate these injustices. So it's how we choose to conduce the research. I think the reason this group was founded was because the way we conduct research isn't the norm and we want to disrupt that paradigm.

AK: Yeah, and so I think that I don't know that transformation even can ever occur with an end product. Transformation can occur when these processes ... RG: Thank you.

AK: ... disrupt or engage with, right? So then at the "end," if you have [fixed] categories and someone has come up with these findings, it can't be transformative because the process is engrained in what's already there. In that way, you can't transform it. So, I think I always have to come back to this 
next time we talk. If you could each send me your sections by next Friday, that would be great.

PP: Sounds good. Ryan, I'll be in the conference call with your students in the advanced qualitative research class next week.

AK: Me too.

RC: I can't but I'll do it next time.

RG: Sounds good. I'll talk with everyone next time.

AK: Have a good week.

RG: Bye! on-going dynamism, ongoing process-oriented work. And we are all too often trained to work against this and come up with an end result. To me, that's sort of what conservative modernization hingesupon,"thinkproduct-oriented,don'tthinkprocessorientated." Because process oriented is too confusing, or it's too exhausting, or this or that. The energy that I have goes into looking at the process.

RG: And the process has no economic value in the conservatively modernized economy.

\section{Introduction /Conclusion}

The Disruptive Dialogue Project (DDP) is a dialogic network of education scholars committed to fostering and engaging in disruptive dialogues on critical issues of higher education scholarship, pedagogy, and methodology. As emerging scholars, we developed the DDP to facilitate our shared interest in interrogating, interrupting, and resisting dominant (positivist and postpositivist) methodological assumptions and research practices that perpetuate the marginalization of critical inquiry within the education research community. Although our scholarship is situated within the context of higher education, the DDP project is part of a broader, interdisciplinary movement within the academy to decolonize research via resistance to and rejection of imperial knowledge production norms which prioritize the pursuit of objectivity and Truth, dismiss politically engaged scholarship, and narrowly define research constructs such as rigor, theory, validity, and expertise (see Brown \& Stream, 2005; Cannella \& Lincoln, 2004a, 2004b; Denzin, 2005; Diverse \& Madeira 2009; Smith, 1999). Thus, in accordance with Dentin's (2005) acknowledgment of the "pressing need for scholars to decolonize and deconstruct those structures within Western academy that privilege Western knowledge systems and their epistemologies" we have conceptualized and enacted the DDP as a space for actively contributing to what Denzin describes as a "decolonizing project [that] reverses this equation, making Western systems of knowledge the object of inquiry" (p. 936).

The dialogic ambitions of the DDP are twofold, one personal and one public. The personal speaks to our desire to create an intimate forum for collaboration, learning, support and renewal as we individually and collectively navigate our way along the tenure track. The public ambition, of equal importance and naturally overlapping with the personal, concerns are intention to establish a space of resistance from which we can critique, challenge, and ultimately overturn the colonizing research practices that continue to constrain the achievement of educational equity and the establishment of socially just educational institutions. These dialogic spaces were not created overnight; the format and nature of the DDP has evolved over time. We have moved from casual conversations at the International Congress of Qualitative Inquiry, to the informal exchange of relevant critical methodology references, to the formal establishment of biweekly "disruptive dialogue" teleconferences and research memos, to national and international conference research paper presentations, to guest speaking in qualitative research courses, to publications. Each provides us with an opportunity to discuss and collectively address the opportunities and challenges embedded in a commitment to conducting decolonizing education research.

The iterative process of the DDP is as important as the content of our discussions and research. As such, this article is a representation of both the content and process surrounding one core topic of discussion - critical research praxis. We have drawn from a number of discussions that occurred between May, 2008 and November, 2009: two recorded and transcribed disruptive dialogue discussions, written minutes and other notes taken from eight disruptive dialogue discussions that were not transcribed, four interconnected symposia papers (which were developed from a number of dialogues), and one PowerPoint presentation (which was created for a national conference). As our discussions are often asynchronous, so is this article. Our hope is that presenting our "disruptive" theorizing in this manner adds to the complexities 
and the interconnections of both the content and process of the DDP and serves as a closer representation of the DDP.

In the above, we explore how early career researchers translate critical theory and the theoretical components of critical methodology into research and daily practice. We wrestle with ethical issues related to constructing critical inquiry praxis within an era of conservative modernization (Apple, 2006). By way of creative representation, we draw from bell hooks and Cornel West's (1991) written rendition of their verbal dialogue in Breaking Bread: Insurgent Black Intellectual Life. hooks and West state that "Dialogue speaks more intimately to people's lived realities" (p. 2) than what is provided on the written page. Their hope was to offer the book in a dialogic format in such a way that mirrored the synergy in their verbal discussions as friends and intellectual colleagues. In a similar vein, we hope to share with readers the synergy and depth of the narratives that have transpired during our ongoing DDP discussions (Gildersleeve et al., 2010; Kuntz, Carducci, Gildersleeve, \& Pasque, 2009).

Furthermore, we complexity the notion of dialogue by drawing on Brahmin's ideas related to dialogue and dialogic process. For Yachting $(1981,1986)$, all speech is in dialogue with other texts - literary, social, aesthetic, and scientificalways drawing from and contributing to the meaning making available from these pluralistic combinations of understanding. As such, our text operates as a dialogue between us, Penny, Rozana, Ryan and Aaron, both in representation but also in its sourcing of understandings from other texts. These texts include formally cited research as well as our collective knowledges from our respective research projects, participants, and daily lives. Each act on another, changing what each can mean - or be - in any given context. Importantly, we hope our texts make contact with readers' texts, each informing the other. In this way, our dialogue seeks to promote a living understanding of ethical imperatives in critical education research.

In accordance with Bakhtin's notions of dialogue and dialogic process, we have not sought a dialectic understanding of critical ethical imperatives. That is, we strive to work against Hegel's (1977) notions that ideologies can be merged in synthesis to create a new compromised tension or understanding. Rather, we engaged in dialogue that can help achieve, as Bakhtin (1986) notes "a deepening with the help of other meanings ... deepening through expansion of the remote context" (p. 160). We present our dialogue pluralistically so as to exacerbate our resistance to synthesis and our commitment to a constant rebuilding of understanding - the infinite interpretations available to any symbolic system, according to Bakhtin (1986). Our pluralist representationoutside of a discrete chronology, but operating from a tenuously chronological endeavor-underscores our commitment to dialogic contact, wherein texts live in contact with other texts, joining these texts to our dialogue. To be clear, we resist the authoritative word.

Notable complexities surround the question "how do we ethically participate in a colonizing institution even as we strive to dislocate ourselves from such a power-laden project?" Though decolonization is never fully completecolonizing acts never completely stripped from contemporary contexts - we seek creative spaces from which to disrupt historically colonizing processes within the academy. The dialogue that is this manuscript is one such creative space. As Denzin (2003) observes, researchers are forced to develop new story lines that reflect the researcher's desire to be connected in collaborative, altruistic partnerships. As such, the reader may engage this text in linear or nonlinear ways: the left side of the page followed by the right; the right followed by the left, back and forth between the left and the right; introduction/conclusion first, middle or last; in concert with other texts; in dialogue between the reader and text; and myriad alternative approaches. In addition, we include the discourse from one of our reviewers while disrupting the normative tendency to incorporate reviewer feedback without acknowledging voice and guidance from reviewers. In this way, there is both the DDP story and representations of the story. Multiple stories are performed; our utterances and sense-making are performative. We actively invite readerwriter-reviewer collaboration and interaction. This dialogic synergy "disrupts" the traditionally singular narrative which, through legitimating practices of reproduction, extends the often-colonialist reach of the academy. We actively resist the singular/dominant narrative through emphasizing the multiple intersection of voices performed in the space of our article.

The conservative modernization of the academy continues (Gildersleeve et al., 2010), yet so does our optimism for critical transformations in education as it gains strength through dialogic processes of support, repair, revision, and critique. We do not reach conclusive answers through our own dialogue, but instead find more productive ways to struggle toward the social change and critical praxis.

\section{Authors' Note}

These authors are part of a collaborative research collective known as the Disruptive Dialogue Project. All authors contributed equally to this manuscript, but have elected an egalitarian authorship rotation order among and across different publication products.

\section{Declaration of Conflicting Interests}

The author(s) declared no potential conflicts of interest with respect to the research, authorship, and/or publication of this article. 


\section{Funding}

The author(s) received no financial support for the research, authorship, and/or publication of this article.

\section{References}

Apple, M. W. (2006). Educating the "right" way: Markets, standards, god, and inequality (2nd ed). New York, NY: Routledge.

Arruda, A. (2003). Living is dangerous: Research challenges in social representations. Culture Psychology, 9, 339-359.

Bakhtin, M. M. (1981). The dialogic imagination: Four essays. In M. Holquist (Ed.), C. Emerson \& M. Holquist (Trans.), Austin: University of Texas Press.

Bakhtin, M. M. (1986). Speech genres and other late essays. V. W. McGee (Trans.), Austin: University of Texas Press.

Bloch, M. (2004) A discourse that disciplines, governs, and regulates: The national research council's report on scientific research in education. Qualitative Inquiry, 10(1), 96-110.

Brown, L., \& Strega, S. (2005). Introduction: Transgressive possibilities. In L. Brown \& S. Strega (Eds.), Research as resistance: Critical, indigenous, \& anti-oppressive approaches (pp. 1-17). Toronto, Ontario, Canada: Canadian Scholars' Press.

Cannella, G. S., \& Lincoln, Y. S. (2004a). Dangerous discourses II: Comprehending and countering the redeployment of discourses (and resources) in the generation of liberatory inquiry. Qualitative Inquiry, 10, 165-174.

Cannella, G. S., \& Lincoln, Y. S. (2004b). Epilogue: Claiming a critical public social science-Reconceptualizing and redeploying research. Qualitative Inquiry, 10, 298-309.

Denzin, N. K. (2003). Performance ethnography: Critical pedagogy and the politics of culture. Thousand Oaks, CA: SAGE.

Denzin, N. K. (2005). Emancipatory discourses and the ethics and politics of interpretation. In N. K. Denzin \& Y. S. Lincoln (Eds.). The SAGE handbook of qualitative research (3rd ed.). Thousand Oaks, CA: SAGE.

Denzin, N. K., \& Giardina, M. D. (2006). Introduction: Qualitative inquiry and the conservative challenge. In N. K. Denzin \& M. D. Giardina (Eds.). Qualitative inquiry and the conservative challenge. Walnut Creek, CA: Left Coast Press.

Diversi, M., \& Moreira, C. (2009). Betweener talk: A Dialogue on decolonizing knowledge production, pedagogy, \& praxis. Walnut Creek, CA: Left Coast Press.

Engestrom, Y. (1999). Activity theory and individual and social transformation. In Y. Engestrom, R. Miettinen, \& R. L. Punamaki (Eds.), Perspectives on activity theory (pp. 19-38). Cambridge, UK: Cambridge University Press.

Fine, M. (1994). Working the hyphens: Reinventing the Self and Other in qualitative research. In N. K. Denzin and Y. S. Lincoln. (Eds.), The SAGE handbook of qualitative research (pp. 70-82). Newbury Park, CA: SAGE.

Fine, M., Weis, L., Weseen, S., \& Wong, L. (2000). For whom? Qualitative research, representations, and social responsibilities. In N. K. Denzin \& Y. S. Lincoln (Eds.), Handbook of qualitative research (2nd ed., pp. 107-131). Thousand Oaks, CA: SAGE.
Foucault, M. (1976). The archeology of knowledge. New York, NY: Harper \& Row.

Galura, J., Pasque, P. A., Schoem, D., \& Howard, J. (Eds.). (2004). Engaging the whole of service-learning, diversity and learning communities. Ann Arbor, MI: OCSL Press.

Gildersleeve, R. E. (in press). Toward a neo-critical validation theory: Participatory action research and Mexican migrant college student success. Enrollment Management Journal.

Gildersleeve, R. E. (2010, May). Re-imagining IRB: A fantasy response to reality. Paper presented at the Congress of Qualitative Inquiry in Urbana-Champaign, IL.

Gildersleeve, R. E., Gomez, C., \& Rodriguez, L. (2009, April). Migrant students and social justice: Inquiry and outreach for freedom and opportunity. Symposium presented at the annual meeting of the American Educational Research Association in San Diego, CA.

Gildersleeve, R. E., Kuntz, A., Pasque, P. A., Carducci, R. (2010). The role of critical inquiry in (re)constructing the public agenda for higher education: Confronting the conservative modernization of the academy. Review of Higher Education. 34(1). 85-121.

Gildersleeve, R. E. \& Los Estudiantes Migrantes y Educación. (2009, April). Los Estudiantes Migrantes y Educación: Participatory action research addressing historic inequality in migrant education. Symposium presented at the annual meeting of the American Educational Research Association in San Diego, CA.

Gildersleeve, R. E. \& Ranero, J. (2008, February). College-going for Latino immigrant students in Iowa: How schools mediate educational opportunity. Paper presented at the annual meeting for the Sociology of Education Association in Pacific Grove, CA.

Gildersleeve, R. E. \& Ranero, J. J. (2010, Fall). The pre-college social and educational contexts of undocumented students. In J. Price (Ed.), New directions in student services: Understanding and supporting undocumented students (No. 131, pp. 19-34). San Francisco, CA: Jossey-Bass.

Greenwood, D. J., \& Levin, M. (2000). Reconstructing the relationships between universities and society through action research. In N. K. Denzin \& Y. S. Lincoln (Eds.), Handbook of qualitative research (2nd ed., pp. 85-106). Thousand Oaks, CA: SAGE.

Hale, C. R. (Ed.). (2008). Engaging contradictions: Theory, politics, and methods of activist scholarship. Berkeley: University of California Press.

Hegel, G. W. (1977). Hegel: The essential writings. New York, NY: Harper \& Row.

hooks, b., \& West, C. (1991). Breaking bread: Insurgent black intellectual life. New York, NY: Between the Lines.

Hytten, K. (2004). Postcritical ethnography: Research as a pedagogical encounter. In G. W. Noblit, S. Y. Flores, \& E. G., Jr. Murillo (Eds.), Postcritical ethnography: Re-inscribing critique (pp. 95-105). New Brunswick, NJ: Hampton Press.

Jones, J. L. (1997). sista docta: Performance as critique of the academy. The Drama Review, 41(2), 51-67. 
Kincheloe, J. L., \& McLaren, P. (2000). Rethinking critical theory and qualitative research. In N. K. Denzin \& Y. S. Lincoln (Eds.). Handbook of qualitative research (2nd ed., pp. 279-313). Thousand Oaks, CA: SAGE.

Kuntz, A. M. (2007). Placing academic activism: Constraints and possibilities of faculty work (Unpublished dissertation). Amherst: University of Massachusetts.

Kuntz, A. M. (2009). Turning from time to space: Conceptualizing faculty work. The Handbook of Higher Education Theory and Research, 24, 355-388.

Kuntz, A., Pasque, P. A., Carducci, R., \& Gildersleeve, R. E. (2009, May). Creating critical space: The disruptive dialogue project. Symposium presented at the International Congress of Qualitative Inquiry, Urbana-Champagne, IL.

Kuntz, A. M., Carducci, R., Gildersleeve, R. E., \& Pleasants, H. (2008, March). Interactive symposium on the intersection of critical qualitative inquiry and civic responsibility. Symposium accepted to the annual meeting of the American Educational Research Association in New York, NY.

Lather, P. (1986). Issues of validity in openly ideological research: Between a rock and a soft place. Interchange, 17(4), 63-84.

Lather, P. (1993). Fertile obsession: Validity after poststructuralism. Sociological Quarterly, 34, 673-693.

Lincoln, Y. S., \& Cannella, G. S. (2004). Dangerous discourses: Methodological conservativism and governmental regimes of truth. Qualitative Inquiry, 10(1), 5-14.

Milner, H. R. (2007). Race, culture, and researcher positionality: Working through dangers seen, unseen, and unforeseen. Educational Researcher, 36, 388-400.

National Research Council. (2001). Scientific research in education. Washington, DC: National Academy Press.

Nilan, P. (2002). "Dangerous fieldwork" re-examined: The question of researcher subject position. Qualitative Research, 2, 363-386.

Pasque, P. A. (2010). American higher education, leadership, and policy: Critical issues and the public good. New York, NY: Palgrave Macmillan.

Pasque, P., Carducci, R., Gildersleeve, R. E., \& Kuntz, A. M. (2008, May). Disrupting the ethical imperatives of "junior" critical qualitative scholars in the Era of Conservative Modernization. Symposium accepted to the Congress of Qualitative Inquiry in Urbana-Champaign, IL.

Pasque, P. A., Franklin, S., \& Luke, S. (2004). Leadership and empowerment: Working to make change. In J. Galura, P. A. Pasque, D. Schoem, \& J. Howard (Eds.), Engaging the whole of service-learning, diversity, and learning communities (pp. 195-205). Ann Arbor, MI: OCSL Press.

Pasque, P. A. \& Kuntz, A. (2006, May). Faculty and early career qualitative scholars: Creating a language for transformative research, teaching and learning. Paper presented at the International Congress of Qualitative Inquiry, Urbana-Champagne, IL.
Potts, K., \& Brown, L. (2005). Becoming an anti-oppressive researcher. In L. Brown \& S. Strega (Eds.), Research as resistance: Critical, Indigenous, and anti-oppressive approaches (pp. 255-286). Toronto, Ontario, Canada: Canadian Scholars Press.

Rogoff, B. (2003). The cultural nature of human development. New York, NY: Oxford University Press.

Sampson, H., \& Thomas, M. (2003). Risk and responsibility. Qualitative Research 3, 165-189.

Schwandt, T. (2006). Opposition redirected. International Journal of Qualitative Studies in Education, 19, 803-810.

Slaughter, S., \& Rhoades, G. (2004). Academic capitalism and the new economy. Baltimore, MA: John Hopkins University Press.

Smith, L. T. (1999). Decolonizing methodologies: Research and Indigenous peoples. New York, NY: Zed.

St. Pierre, E. A. (2004). Refusing alternatives: A science of contestation. Qualitative Inquiry, 10(1), 130-139.

Stage, F. K. (2007). Answering critical questions using quantitative data. In F. K. Stage (Ed.), Using quantitative data to answer critical questions: New Directions for Institutional Research, $133,5-16$.

Stanley, C. A. (2007). When counter narratives meet master narratives in the journal editorial-review process. Educational Researcher, 36(1), 14-24

Trenholm, S., \& Jensen, A. (1992). Interpersonal Communication (2nd ed.). Belmont, CA: Wadsworth.

\section{Bios}

Penny A. Pasque is assistant professor in the Department of Educational Leadership and Policy Studies and Women's and Gender Studies at the University of Oklahoma. Her research addresses in/ equities in higher education, dis/connections between higher education and society, and complexities in critical inquiry. Her latest book is American Higher Education, Leadership, and Policy: Critical Issues and the Public Good (Palgrave Macmillan).

Rozana Carducci is an assistant professor in the Department of Educational Leadership and Policy Analysis at the University of Missouri. Her research interests include higher education leadership, academic capitalism, and critical inquiry.

Ryan Evely Gildersleeve strives to be a social scient(art)ist while playing the role of associate professor at The University of Texas at Arlington. His research focuses on educational opportunity and critical inquiry. He is the author of Fracturing Opportunity: Mexican Migrant Students and College-going Literacy (Peter Lang). He is a graduate of Occidental College.

Aaron M. Kuntz is assistant professor of qualitative research methods at the University of Alabama. His research interests include critical geography, academic citizenship and activism, materialist methodologies and critical inquiry. 